\title{
"Insurance instruments in risk management of the manufacturing sector of a region: the case of the Republic of Khakassia (Russia)"
}

\begin{tabular}{|c|c|}
\hline AUTHORS & $\begin{array}{l}\text { Evgenija Prokopjeva } \text { https://orcid.org/0000-0002-6818-5780 } \\
\mathbb{R} \text { https://publons.com/researcher/2146950// } \\
\text { Galina Chernova (D https://orcid.org/0000-0003-4050-4046 } \\
\mathbb{R} \text { https://publons.com/researcher/2355356/galina-v-chernova/ } \\
\text { Nataliya P. Kuznetsova } \mathbb{D} \text { https://orcid.org/0000-0002-3612-9127 } \\
\mathbb{R} \text { https://publons.com/researcher/2455281/natalia-p-kuznetsova/ } \\
\text { Svetlana Kalayda } \mathbb{D} \text { https://orcid.org/0000-0002-5688-3178 } \\
\mathbb{R} \text { https://publons.com/researcher/2583595/svetlana-kalaida/ } \\
\text { Leonid Ivanov } \mathbb{D} \text { https://orcid.org/0000-0001-9513-8712 } \\
\mathbb{R} \text { https://publons.com/researcher/2097036/leonid-alekseevich-ivanov/ }\end{array}$ \\
\hline ARTICLE INFO & $\begin{array}{l}\text { Evgenija Prokopjeva, Galina Chernova, Nataliya P. Kuznetsova, Svetlana } \\
\text { Kalayda and Leonid Ivanov (2020). Insurance instruments in risk management of } \\
\text { the manufacturing sector of a region: the case of the Republic of Khakassia } \\
\text { (Russia). Investment Management and Financial Innovations, 17(4), 299-314. } \\
\text { doi:10.21511/imfi.17(4).2020.26 }\end{array}$ \\
\hline DOI & http://dx.doi.org/10.21511/imfi.17(4).2020.26 \\
\hline RELEASED ON & Thursday, 10 December 2020 \\
\hline RECEIVED ON & Wednesday, 28 October 2020 \\
\hline ACCEPTED ON & Monday, 07 December 2020 \\
\hline LICENSE & $\begin{array}{l}(c) \text { EY } \\
\text { This work is licensed under a Creative Commons Attribution } 4.0 \text { International } \\
\text { License }\end{array}$ \\
\hline JOURNAL & "Investment Management and Financial Innovations" \\
\hline ISSN PRINT & $1810-4967$ \\
\hline ISSN ONLINE & $1812-9358$ \\
\hline PUBLISHER & LLC “Consulting Publishing Company "Business Perspectives" \\
\hline FOUNDER & LLC "Consulting Publishing Company "Business Perspectives" \\
\hline
\end{tabular}

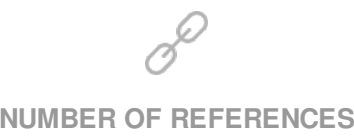

51

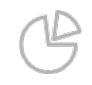

NUMBER OF FIGURES

8

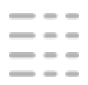

NUMBER OF TABLES

2

(C) The author(s) 2023. This publication is an open access article. 


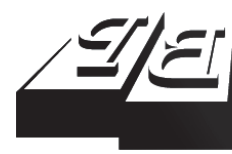

BUSINESS PERSPECTIVES

(2)

LLC "CPC "Business Perspectives"

Hryhorii Skovoroda lane, 10,

Sumy, 40022, Ukraine

www.businessperspectives.org

Received on: $28^{\text {th }}$ of October, 2020

Accepted on: $7^{\text {th }}$ of December, 2020

Published on: $10^{\text {th }}$ of December, 2020

๑ Evgenija Prokopjeva, Galina

Chernova, Nataliya Kuznetsova,

Svetlana Kalayda, Leonid Ivanov, 2020

Evgenija Prokopjeva, Ph.D. in Economics, Associate Professor of the Department of Economics and

Humanities, Khakass technical Institute - branch of Siberian Federal University, Russian Federation. (Corresponding author)

Galina Chernova, Doctor of Economics, Professor of the Department of risk Management and insurance, St. Petersburg state University, faculty of Economics, Russian Federation.

Nataliya Kuznetsova, Doctor of Economics, Professor of the Department of risk Management and insurance, St. Petersburg state University, faculty of Economics, Russian Federation.

Svetlana Kalayda, Ph.D. in Economics, Associate Professor of the Department of risk Management and insurance, St Petersburg state University, faculty of Economics, Russian Federation.

Leonid Ivanov, Ph.D. in Technical Sciences, Chief Scientific Secretary to RAE (Russian Academy of Engineering), Russian Federation.

This is an Open Access article, distributed under the terms of the Creative Commons Attribution 4.0 International license, which permits unrestricted re-use, distribution, and reproduction in any medium, provided the original work is properly cited.

Conflict of interest statement: Author(s) reported no conflict of interest

Evgenija Prokopjeva (Russian Federation), Galina Chernova (Russian Federation), Nataliya Kuznetsova (Russian Federation), Svetlana Kalayda (Russian Federation), Leonid Ivanov (Russian Federation)

\title{
INSURANCE INSTRUMENTS IN RISK MANAGEMENT OF THE MANUFACTURING SECTOR OF A REGION: THE CASE OF THE REPUBLIC OF KHAKASSIA (RUSSIA)
}

\begin{abstract}
Socio-economic development of a region is based on its production capacity. However most regions in Russia are characterized by financial instability of local enterprises and the lack of a balanced structure of the regional economy. Insurance is an instrument of financial protection against risks, and its effective functioning is important for the development of the manufacturing sector, especially in depressed regions.
\end{abstract}

This paper aims to highlight the mechanisms for increasing the production capacity of a region and reducing business risks with the help of insurance instruments and to provide appropriate recommendations for the development of the insurance market. This is planned to be achieved on the basis of analysis and processing of existing scientific research in this field and statistical materials.

For this, a typology of regions was developed, which reflects the level of production in the region and is important in terms of developing the regional insurance market. This allows assessing the impact of insurance coverage in the region on the development of its production capacity. The proposed typology allows determining the causes of production inefficiency. The conformity of the development of the regional insurance market to the needs for insurance coverage of the production sector in the region was assessed. The identified imbalance between the provision of insurance coverage and the need for it allowed demonstrating an additional need for insurance, as well as working out a program for its development.

The obtained results are illustrated using the example of the Republic of Khakassia, a constituent entity of the Siberian Federal District of the Russian Federation. To implement risk management in the manufacturing sector, schemes of interaction between insurance market participants using commercial and non-commercial insurance are proposed.

Keywords

JEL Classification

\section{INTRODUCTION}

Socio-economic conditions of the functioning and development of countries and regions differ significantly from each other. In many regions of the Russian Federation, the extractive industry is the basis of the real sector of the economy, due to the geographic, climatic and natural resource characteristics of the country. The current situation causes many economic problems, such as poor diversification of the production structure of the economy in most Russian regions, limited investment and tax opportunities, and lack of financial infrastructure, including insurance. The vast majority of RF entities depend on subsidies from the federal budget. For such regions, the importance of the 
development of the insurance market is unquestionable, since it not only ensures the financial security for economic entities, but also intensifies their financial and investment activities in remote regions of the country. In the meantime, it should be combined with the existing regional needs, contributing to the further effective development of the region.

The purpose of the paper is to highlight the mechanisms of strengthening the production capacity of the region and reducing business risks through insurance instruments and provide appropriate recommendations on the development of the insurance market.

It is assumed that insurance is a concept of financial protection against economic risks. Therefore, to develop the regional insurance market aimed at revealing and strengthening the production capacity of the region, it is necessary:

- to assess the real level of development of the manufacturing sector in the region. To this end, it is proposed to consider the region typologies used in practice, reflecting the level of production in the region, on the one hand, and significant in terms of the development of the regional insurance market, on the other;

- to use the typologies to describe the real level of production in the region and identify problems;

- to link the real level of production in the region with the risks posed by the manufacturing sector of the region;

- to analyze the level of development of the regional insurance market in order to assess the real situation with the use of insurance types.

These tasks are considered using the Republic of Khakassia as an example.

\section{LITERATURE REVIEW}

Since the role of the insurance sector and its contribution to economic development is one of the paramount issues, the importance of studying the relationship between financial development and economic growth is emphasized (Outreville, 2013; Prokopjeva, 2020). Njegomir and Stojić (2010) focus on the impact of insurance on the indicators of economic growth, which is more effective in interaction with the banking sector. In developing economies, insurance growth rates are significant, and its impact on economic processes is more pronounced. Mohy et al. (2017) illustrated this relationship by the cases of China, India, Pakistan and Malaysia. In particular, they confirm the existence of a significant causal relationship between the development of insurance and economic growth indicators in the country and regions. However, these connections manifest themselves differently due to different income levels and locations. It is also noted that the impact of insurance devel- opment on a country's economic growth significantly depends on the efficiency of investments by insurers (Lee et al., 2018).

Insurance improves financial stability, thereby facilitating trade and business development (Mdanat et al., 2019). However, there are opinions that the impact of long-term insurance on economic growth is non-uniform. Econometric results show that, on the one hand, the development of insurance has a positive effect on GDP per capita, and on the other hand, this effect varies depending on the economy's structural characteristics (Ouédraogo et al., 2016).

In the last decade, the processes of financial convergence, characteristic of both European and Asian countries of different levels and dynamics of development, have intensified (Kuznetsova \& Pisarenko, 2017).

It is worth noting the research on the interaction of the insurance market and the national econo- 
my. Thus, Mnykh (2017) notes that the effective development and growth of the insurance market in modern conditions is determined by two factors, such as competition and competitiveness of insurance companies.

The efficiency of the insurance market at the regional level is determined by the existing state regulation mechanism in a country (Efimov \& Kochubey, 2017; Orlanyuk-Malitskaya, 2017; Belozyorov, 2018).

Chalmers and Reuter (2012), Laux and Muermann (2010), and Lobo-Guerro (2014) discuss the problematic issues of the functioning of regional insurance markets and their impact on economic development in different countries.

Some authors agree on the uneven development of regional insurance markets, due to the influence of different factors in the regions and the presence of various risks (Belozyorov et al., 2018; Porrini, 2017).

Alyakina et al. (2018), Tarasova and Voskovskaya (2018) considered the risks of the functioning and development of regions, their specificity and causes of occurrence. Blake (2013), Kalaida and Chernova (2016), and Shkolnyk et al. (2019) studied the risks arising in financial markets and the risks inherent in financial convergence processes. Yakymchuk et al. (2017) focus on the possibilities of insurance protection of a region with significant nature reserves.

Gaganis et al. (2016) indicate that national characteristics and organizational and legal factors of the insurance market in a particular country affect the level of internal regional risks.

Different classifications of development factors of regions and their insurance markets are also offered (Kuzmenkova, 2016; Pchela, 2016). Vorontsov (2014), Kuznetsova et al. (2019), Tarasova and Voskovskaya (2018) agree that the sustainable development of individual regions depends on all-Russian and regional factors.

There is little research on regional in-country insurance problems, faced primarily by geographically enlarged countries. Studies show that the impact of insurance on economic growth in such countries is determined by production efficiency and marginal income in specific regions (Zheng \& Zhao, 2017), that is, the dynamics of insurance premiums is largely determined by the situation in the labor market. Thus, the growth of the personal insurance market, including life insurance, is determined by the dynamics of employment and wages, as an increase in income entails an increase in insurance premiums. That is why the fast-growing economies of Asia and Latin America show the highest growth rates of their insurance markets. An example is the rapidly growing Chinese market, which is also characterized by a fairly high concentration (Sigma, 2019).

Arkhipov (2017) studies the development risks of the Russian insurance market. Belozyorov et al. (2018) and Chernova et al. (2017) analyze the factors influencing the development of insurance at both the federal and regional levels of government, while Prokopjeva (2019) and Rusetskaya (2013) consider problems and promising directions of the insurance market development in the Russian Federation and regions.

Alyakina (2018) and Domnina (2018) consider the risks of regional insurers in Volga Federal District companies. Keneshova (2018) and Prokopjeva (2018) use economic and mathematical methods to assess regional insurance markets.

Tsvetova and Stemkovskaya (2018) emphasize the importance of regional insurance markets as one of the main factors of regional economic development, growth in investment activity, increase in social and economic stability in society and confirm this using the insurance market of the Far Eastern Federal District as an example.

An important component of regional insurance is life insurance, the development of which will contribute to a greater coverage of potential policyholders, ensure the availability of insurance services for all categories of citizens and legal entities (Chernyavskaya \& Izyumova, 2018).

Kirillova (2018) pays special attention to regional insurance policy. Tarasova et al. (2018) and Tsyganov and Kirillova (2018) assess the impact of the regional insurance market on the insurance 
market of the Russian Federation, and Vorontsov (2014) - on the development of the regional economy.

It is proposed to consider the example of the Republic of Khakassia, which is a subject of the Siberian Federal District (SFD). SFD includes 10 constituent entities of the Russian Federation, including republics, territories and regions. Its territory is about $30 \%$ of Russia. The area of the Republic of Khakassia is $61,569 \mathrm{~km}^{2}$ (this is $1.2 \%$ of the territory of the Siberian Federal District and $0.4 \%$ of the territory of the Russian Federation). It includes five cities and eight districts. The regional economy is based on hydropower and aluminum production. Coal mining, which has been growing rapidly in recent years, also accounts for a significant share of the region's manufacturing sector. There are conditions for the development of agriculture, both crop and animal production. At the same time, Khakassia is an area of risky agriculture, where severe weather conditions are regularly observed, so there are natural and climatic risks.

In Russia, the typology of regions can be determined by the spatial concentration of a particular economic sector, that is, they can be mono-industry (metallurgical, agricultural, etc.) and multi-industry (with a diversified structure of the regional economy).

Figure 1 shows the production structure of the economy of Russia, the Siberian Federal District and the Republic of Khakassia (RKh) (Federal State Statistics Service, 2019).

The main industries of the Republic of Khakassia, in addition to manufacturing and extractive industries ( $20 \%$ and $12.5 \%$, respectively), are the energy industry (15\%) and trade (12.4\%). However, the region's economy is still based on the extractive industry, as it provides GRP growth.

Figure 2 shows the structure of the extractive industry (Federal State Statistics Service, 2019).

All of these industries are harmful and dangerous, which indicates the existence of many regional risks that require organizational, technical, technological and financial protection. Risks inherent in coal mining are the most significant for the region, they are: environmental risk, the risk involved in the operation of hazardous industrial facilities (explosive production), and health risks for both coal workers and all residents.

The manufacturing industry is also of great importance for the region's economy. Figure 3 shows the structure of the manufacturing sector (Federal State Statistics Service, 2019).

Russia's manufacturing industry as a whole is characterized by an even distribution of production by industry. In the Siberian Federal District, there is already an imbalance, and in Khakassia,

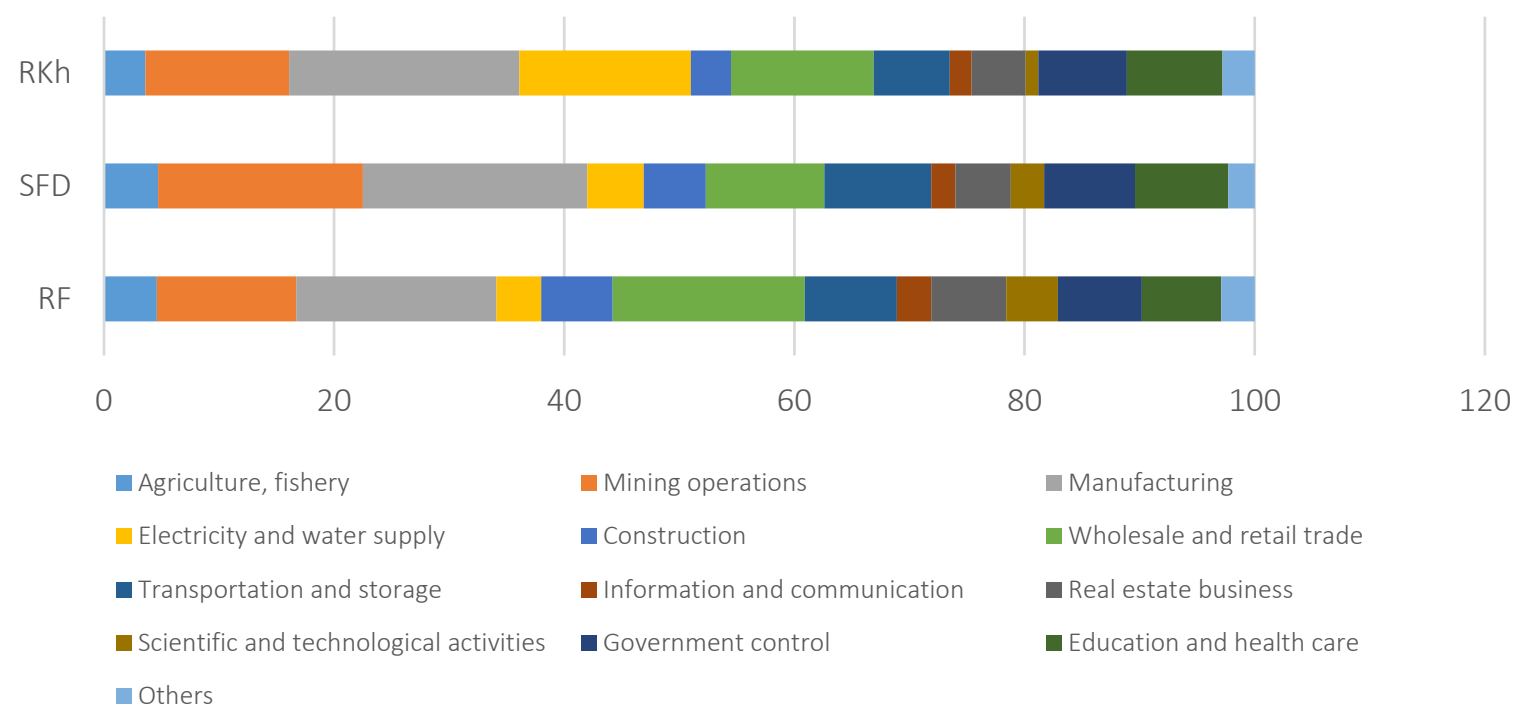

Figure 1. GDP/GRP structure by value added in $2018, \%$ 


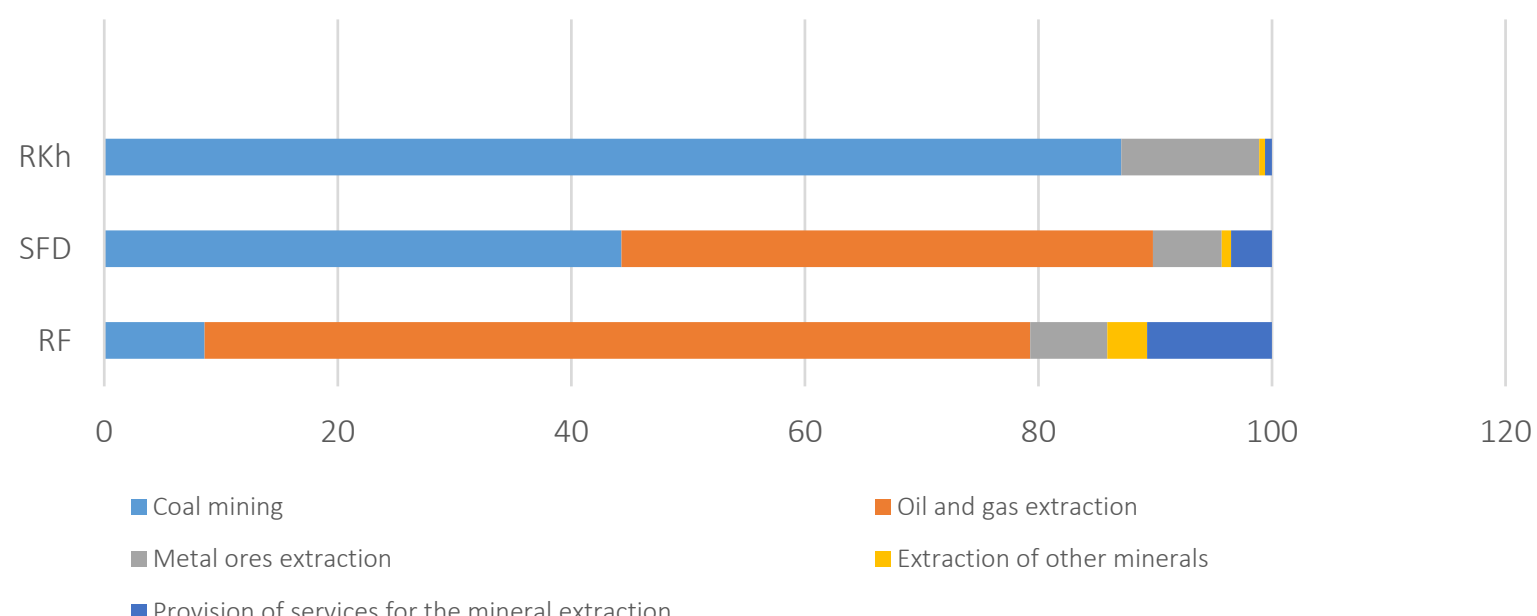

Figure 2. The structure of the extractive industry by production volumes in 2018 , \%

the metallurgical industry absolutely prevails (over $70 \%)$. Food industry (11\%) and the repair of machinery and equipment $(9.2 \%)$ rank second. Metallurgical production in Khakassia is represented by the production of aluminum and aluminum products. Low diversification of manufacturing in the region is a problem of balanced sustainable economic development and is associated with underdevelopment of small and medium-sized businesses, as well as low investment activity. One of the main industries in Khakassia is the production of electricity, which is produced by the most powerful hydroelectric power plant located here.

As one can see, the economy of Khakassia is characterized by a mono-industry orientation, which is also characteristic of most constituent entities of the Siberian Federal District.
The problem of such cities is weak innovation and investment activity due to the limited financial capabilities of the enterprises themselves and the lack of other investors (Zainutdinov, 2015). The concentration of mono-industry cities in the Siberian Federal District is typical of the Kemerovo region, where there are 24 of them. The main cities' specializations are coal mining, non-ferrous metallurgy, power engineering, and woodworking. There are six mono-industry settlements in Khakassia. These are the cities of Abaza, Sayanogorsk, Sorsk, Chernogorsk, Vershina Tyoi, and Tuim. The total share of industrial production of these municipalities is over $77 \%$ of the total industrial production of the region.

The mono-industry structure of the economy entails the following features of the region's devel-

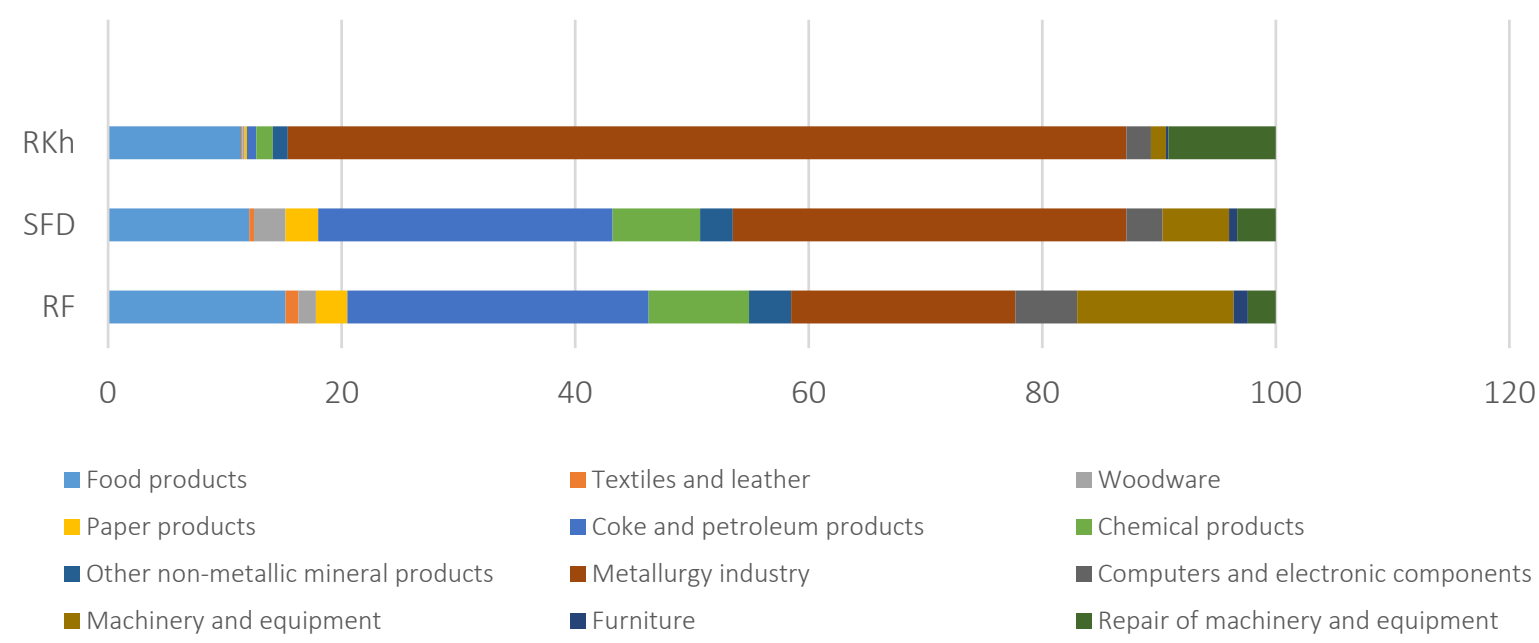

Figure 3. The structure of the manufacturing industry by production volumes in $2018, \%$ 
opment: high environmental risk associated with the predominance of metallurgical, coal and other industries; dependence of citizens' incomes on the activities of city-forming enterprises; monopoly pricing of mining products; a small share of small and medium-sized businesses due to the lack of a competitive environment.

According to the typology of the country's regions by regional economic climate, all regions are divided into those characterized by economic growth, stagnant, and depressive. Such a classification is possible on the basis of the "rate of change in gross regional product (GRP)" (Federal State Statistics Service, 2019a), although it does not always give an objective picture, since regions often increase economic growth due to the raw materials sector.

Over the past seven years, the regions of the Siberian Federal District have seen a marked decline in the GRP rates in Khakassia, Tyva and the Tomsk region, where the average annual GRP growth is less than $100 \%$. Given that the average annual GDP growth in Russia during the period under review was $101.5 \%$, regions with similar GRP growth rates can be classified as stagnant.

According to the typology of the country's regions, based on the geographic location and the effect of agglomeration, the regions are divided into growing megalopolises, agricultural regions and depressed regions.

There are 15 megacities in Russia, or as they are called, "cities with a million-plus population". They are concentrated in central Russia or are the capitals of administrative-territorial units. Agricultural regions usually do not exist in their pure form, as a rule, the agro-industrial complex simply occupies a large share in the GRP structure. These include mainly the constituent entities of the Central, Volga and Southern Federal Districts.

The most depressed are the regions where the extractive structure of the economy prevails. The region's depressiveness has a negative impact on all its socio-economic processes. Factors that determine it are some features of the geographical location of the region (for example, distance from the center); historical features and administrative-territorial division; natural and climatic conditions that determine the settlement of inhabitants, etc.

The depressed regions of the Siberian Federal District include the Republic of Khakassia, Altai, Tyva and the Trans-Baikal Territory (Comments on the State and Business, 2016).

There is a typology of the country's regions based on their problematic nature. Factors that significantly affect the rates and volumes of development of individual regions are the availability of potential in the region to realize the country's strategic interests and the adequacy of financial and other resources for its implementation. The different ratio of these two factors leads to the fact that, in addition to the regions in which both factors are present (primarily the regions of the European part of Russia), there are also problem regions with a potential for the realization of the country's strategic interests (the first factor is present), but financial and other resources are not enough for its implementation (the second factor is missing).

Problem regions are divided into national-territorial formations (Caucasus and Southern Siberia) and regions of new development (North, Far East).

The territory of Siberia is of strategic importance; the most significant are the fuel and energy resources located here, which confirms the existence of potential in its territory to realize the strategic interests of the country. However, given the financial capacity of the region and the level of its budget support, it becomes clear that most regions of the Siberian Federal District are problematic.

The biggest problems in integrated development are characteristic of the regions of new development and national-territorial entities. The former require significant financial investments that are not immediately profitable, the latter are usually inert to innovations. The second group includes Khakassia, where the budget provision index is 0.65 . At the same time, there is an increase in the budget deficit and public debt. Thus, as of December 1, 2019, the total amount of public debt of the Republic of Khakassia amounted to 20,734 million rubles, of which $65 \%$ were budget loans, $28.5 \%$ were government securities, and $8 \%$ commercial debt. For comparison, in 2017, the budget revenues of the Republic of Khakassia amounted 
to 18 billion rubles, and for 2018 and 2019 they are planned at 19 billion rubles (Ministry of Finance of the Republic of Khakassia, 2019). If a region's debt is comparable to its revenue, this characterizes the region as close to default.

Despite the difficult economic situation, Khakassia remains a strategically important region for the country, as it employs non-ferrous metallurgy, coal mining, energy production and other enterprises, many of which are export-oriented.

Typology of the country's regions based on the level of environmental risk - regions with high, medium and low environmental risks. This classification is important for the study of regions with an economic structure with a predominance of the industrial sector, which includes, in particular, the Republic of Khakassia.

The level of environmental risk is growing steadily across the country. This is due to the extensive path of economic development. The latter causes significant damage to natural resources and the environment.

However, many constituent entities of the Russian Federation are now paying close attention to environmental safety, which can significantly reduce environmental risks. Nevertheless, a number of Siberian regions are the most environmentally polluted. These include cities where metallurgical, oil and energy industrial enterprises are located - Norilsk, Novokuznetsk, Omsk, Krasnoyarsk, Novosibirsk, Angarsk, Bratsk (All-Russian Public Organization Green Patrol. National environmental rating of regions, 2018).

Among the regions of the Siberian Federal District are both environmentally friendly and polluted, the latter predominate. The Siberian Federal District itself ranks 7th among eight federal districts, which indicates serious environmental problems. In terms of environmental risk, Khakassia ranks 30th out of all constituent entities of the Russian Federation. However, environmental hazards in the region are increasing in influence - this includes a largescale increase in the volume of production by coal industry and non-ferrous metallurgy enterprises, as well as the use of mineral fertilizers in agriculture. Industrial enterprises in neighboring regions, whose emissions are carried by the wind, also cause environmental damage. But the main source of environmental danger is the Sayano-Shushenskaya hydroelectric power station. Its risks are as follows - the likelihood of flooding the territory; the rise of groundwater leads to waterlogging; due to humidity the climate changes.

These typologies of regions make it possible to identify significant factors in their development and, as a consequence, the factors of their production capacity and the associated risks.

Solving the problem of reducing risks and protecting the region from them determines the study of the regional insurance market as an institution of social and financial protection against risks, as well as the need to develop recommendations (using the example of Khakassia) aimed at supporting and developing the manufacturing sector and ensuring the integrated development of the region's economy.

According to the considered typology, the Republic of Khakassia is presented as a region with economic potential, characterized by the predominance of the coal mining, metallurgy and energy industries. All this provokes an increase in man-made, industrial and environmental risks in the region, protection from which is currently extremely weak.

Therefore, to ensure comprehensive protection of the region from risks, it is necessary to consider the already used and possible insurance mechanisms.

\section{GENERALIZATION OF THE MAIN STATEMENTS}

The structure of the insurance market is formed subject to the needs of the region in certain insurance products. Figure 4 shows the structure of the insurance market of the Siberian Federal District, which is determined by the amount of insurance premiums raised in 2018 (The Central Bank of the Russian Federation, 2019).

The largest insurance markets in the Siberian Federal District are the Novosibirsk, Irkutsk, 


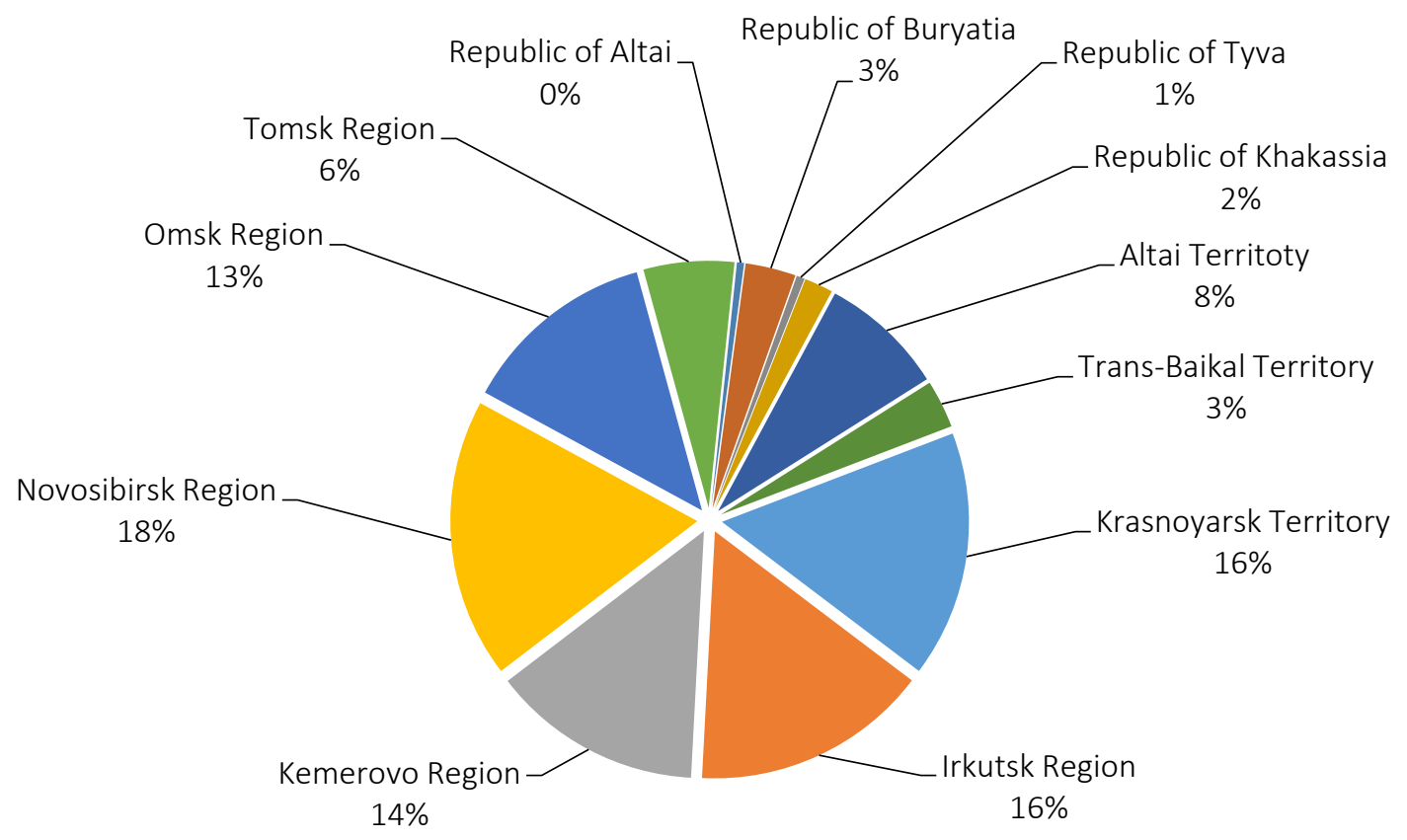

Figure 4. Insurance premium structure of the Siberian Federal District by the constituent entities of the Russian Federation in 2018

Kemerovo, Omsk regions and the Krasnoyarsk Territory. The remaining regions occupy less than $10 \%$ of this structure. The Republic of Khakassia accumulates only $2 \%$ of the total premium for the federal district. However, the structure reflects only the total amount of insurance premiums. Figure 5 shows the structure of premiums in the constitu- ent regions of the Siberian Federal District by type of insurance (The Central Bank of the Russian Federation, 2019).

Life insurance and Compulsory Motor Third Party Liability (CMTPL) prevail in economically backward regions. Such regions include the Republic

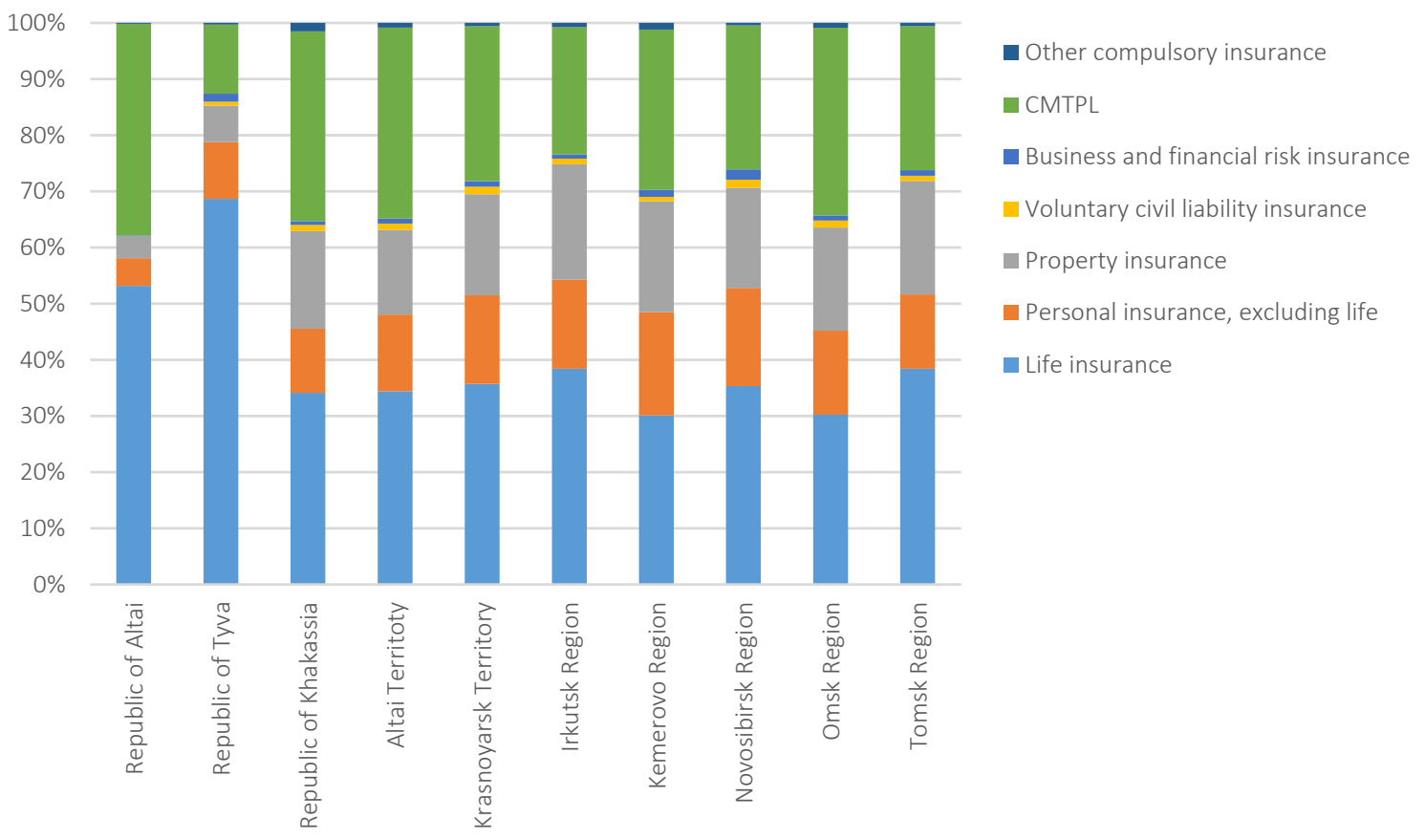

Figure 5. Insurance premium structure by constituent entities of the Siberian Federal District in 2018 


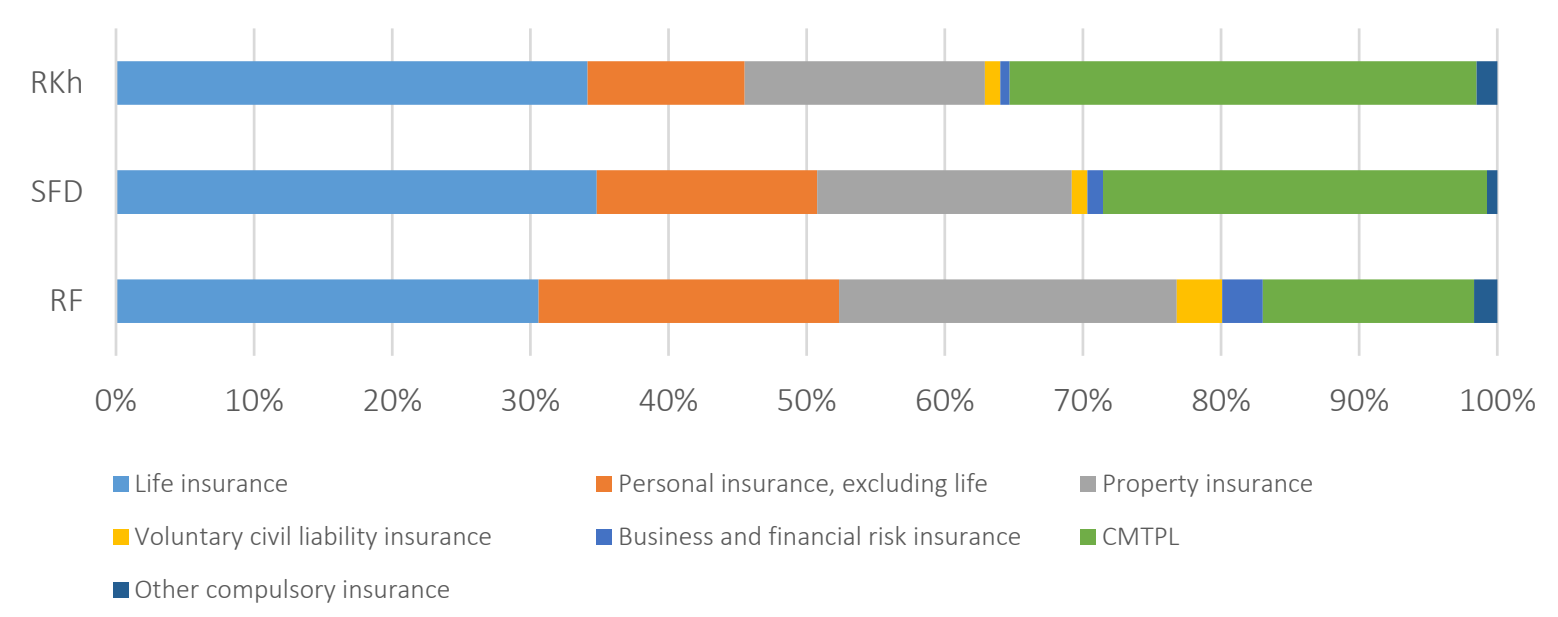

Figure 6. Distribution of insurance premiums by type of insurance in 2018

of Tyva, the Republic of Altai and the Republic of Khakassia. This allows one to conclude that in regions with low economic activity and the absence of a diversified manufacturing industry, insurance funds are formed mainly by insuring risks of individuals and by compulsory insurance.

Figure 6 shows the structure of insurance premiums in Russia, the Siberian Federal District and the Republic of Khakassia by main types of insurance (The Central Bank of the Russian Federation, 2019).

In Khakassia, personal insurance (health and accident insurance), property insurance of enterprises and citizens account for a small share. In Khakassia and in the Siberian Federal District, business and financial risk insurance and voluntary liability insurance are limited. It is the types of risks that are important for the sustainable development of the region's economic potential that are not adequately covered by insurance.

In general, the insurance market of the Republic of Khakassia has the following development features:

- the market is represented exclusively by branches of nonresident insurers, which leads to the lack of regional orientation of insur- ers' policy (Table 1) (The Central Bank of the Russian Federation, 2019);

- there is a high concentration of the insurance market, in which large insurers determine market policy, including pricing policy;

- the development of compulsory types of insurance and standard types of voluntary insurance prevails; and

- there is no investment activity of insurers in the region.

The existing structure of the insurance market in the Republic of Khakassia is determined by the following two groups of factors:

\section{Primary factors:}

- availability of various natural resources and minerals;

- the absolute predominance of several industries, primarily mining;

- features of the development of the national republic, including low receptivity to innovation;

Table 1. Dynamics of the number of insurance companies

\begin{tabular}{|c|c|c|c|c|c|c|c|}
\hline Number of insurers & 1.01 .13 & 1.01 .14 & 1.01 .15 & 1.01 .16 & 1.01 .17 & 1.01 .18 & 1.01 .19 \\
\hline Russian Federation & 469 & 432 & 416 & 364 & 297 & 226 & 199 \\
\hline Republic of Khakassia (branches) & 43 & 47 & 48 & 45 & 44 & 53 & 51 \\
\hline
\end{tabular}


- presence of man-made and natural risks;

- limited foreign economic relations of the region, mainly represented by exports of raw materials.

\section{Secondary factors:}

- low budget support for the region;

- low investment attractiveness and innovative activity;

- stressful environmental situation due to the expansion of coal production;

- favorable conditions for the development of agriculture;

- poorly diversified (mono-industry) structure of the economy;

- a small proportion of small and medium enterprises;

- low income of citizens and outflow of labor from the region.

These factors determine the negative impact on the development of the regional economy and the regional insurance market. Given the structure of the regional economy, its development potential, as well as the existing structure of the insurance market and the need for insurance services, a number of measures are needed to ensure insurance coverage in the region in such a quality and volume that would give impetus to effective production, financial, investment, and social potential of the region.

The main direction of the regional economic policy in Khakassia should be the diversification of the economy, including the implementation of vertical integration in industry (extractive and processing industries). The competitive advantage of the region may be its agrarian potential, which currently makes a small contribution to the region's production. Sources of available investment resources are needed to intensify these areas of regional development. One of such sources may be the development of the insurance market, which accumu- lates large investment resources, which implies the presence of regional insurance companies.

The insurance market significantly contributes to solving these problems. It supports the financial sustainability of insured companies in the implementation of various risks associated with production activities. Therefore, the creation of regional insurance organizations with the assistance of regional authorities or large enterprises of the regional level is the most important direction of insurance development in the region.

In Russia, regional insurance companies are scattered. Table 2 shows the distribution of registered insurance entities (IE) by federal district (The Central Bank of the Russian Federation, 2019).

Table 2. Distribution of insurance entities by federal district in 2018

\begin{tabular}{l|c|c}
\hline \multicolumn{1}{c}{ Regions } & $\begin{array}{c}\text { Number of } \\
\text { registered IE }\end{array}$ & Share, \% \\
\hline Central Federal District & 183 & 69.3 \\
\hline Including Moscow & 170 & 64.4 \\
\hline Northwestern Federal & 20 & 7.6 \\
District & 18 & 6.8 \\
\hline Including St. Petersburg & 6 & 2.3 \\
\hline Southern Federal District & 0 & 0 \\
\hline North Caucasian Federal & 20 & 7.6 \\
District & 13 & 4.9 \\
\hline Volga Federal District & 14 & 5.3 \\
\hline Ural Federal District & 8 & 3 \\
Siberian Federal District & & \\
\hline Far Eastern Federal & & \\
District & &
\end{tabular}

$70 \%$ of entities are registered in the Central Federal District, while in the Siberian Federal District only $5.3 \%$. In Khakassia, as in many Russian regions, there are no insurers at the regional level - as of January 1,2019, there were 46 such entities of the Russian Federation (The Central Bank of the Russian Federation, 2019). This leads to a lack of interest of branches in expanding the coverage of insurance objects and optimizing the pricing policy set by the parent company. Branches of insurers in the regions often provide compulsory insurance services, and to keep profitability, in addition to them, they try to sell voluntary insurance policies. Such sales and follow-up schemes are of low quality. Therefore, the development of its own competitive insurance market is an urgent problem for any region of the Russian Federation. 
A regional insurance organization may be established by the authorities of a constituent entity of the RF to provide types of insurance that are important for the region, in cases where the relevant insurance services are either not provided by nonresident insurers, or are sold by them in a limited amount, while the cost of these services for this region is overstated (the latter parameters are estimated by the ratio of insurance payments to premiums or by inter-regional comparison).

A regional company should be focused, first of all, on the prospects for development of insurance in the region by implementing priority directions of insurance and providing the following services:

3) insurance of property of enterprises, covering production, business, investment and agricultural risks;

4) insurance of property of citizens, first of all, housing;

5) voluntary insurance against accidents at work, voluntary health insurance, primarily at the expense of large enterprises that are dangerous

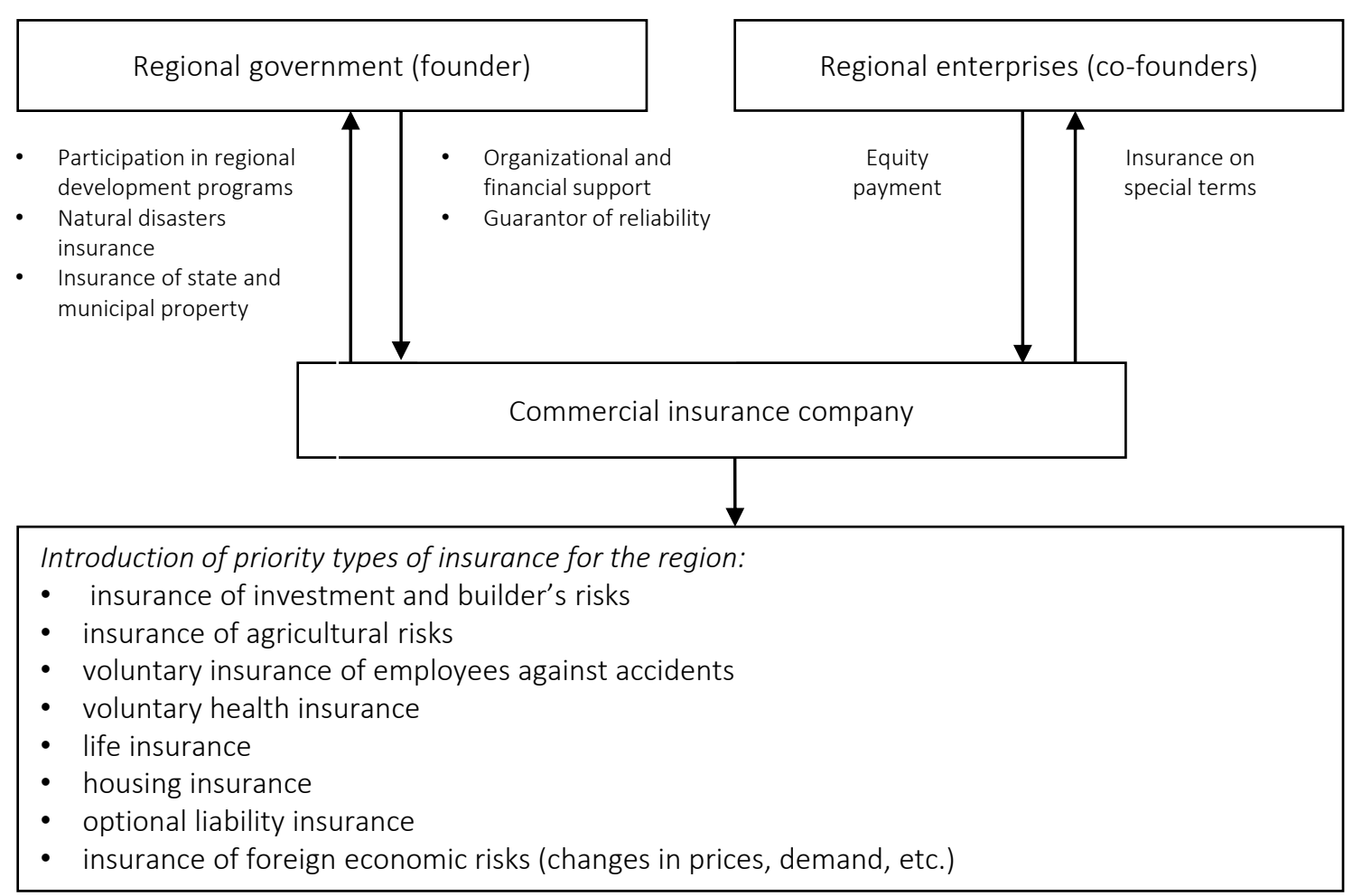

objects and pollute the environment. Voluntary health insurance (VHI) should be aimed at early diagnosis of cancer and other diseases associated with harmful working and living conditions;

6) environmental risk insurance and other types of liability insurance.

Regional insurers can be created in two forms: a commercial insurance company and a mutual insurance society (MIS).

The cost of insurance through MIS can be much lower. Its scope usually includes the highest or specific risks that commercial insurance companies are reluctant to accept. As a non-profit organization, MIS has tax benefits. However, the problem of organizing an MIS in a small region is high organizational costs that must be borne by stakeholders. There are also legal restrictions on the activities of MIS: they can only insure property risks and cannot engage in compulsory insurance (Law of the Russian Federation On Mutual Insurance, 2007).

The scope of activity of commercial insurance companies is quite wide with the appropriate li-

Figure 7. Scheme of interaction between participants when creating a regional commercial insurance company 


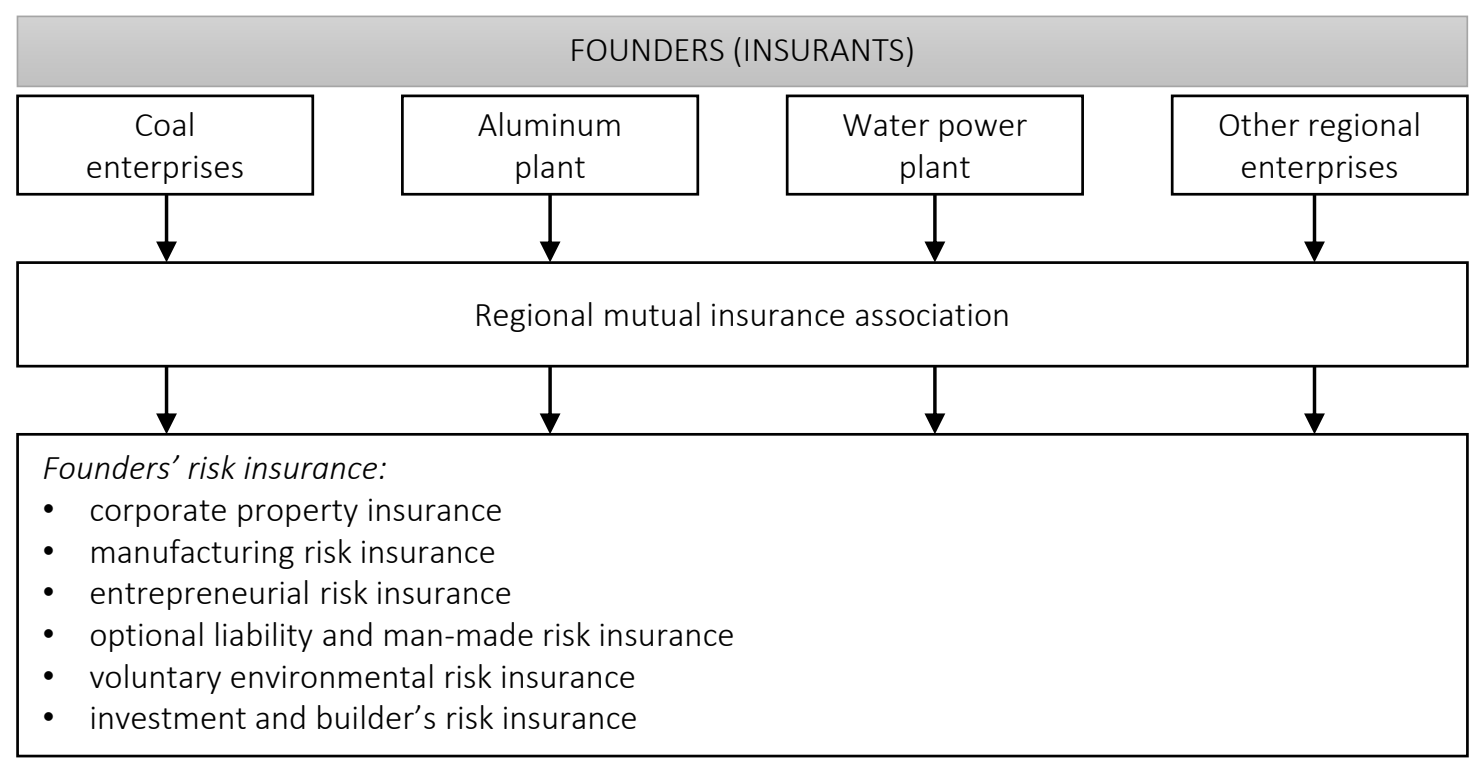

Figure 8. Scheme of interaction between participants when creating a regional MIS

cense. However, the cost of their insurance services will be slightly higher, and market entry is more difficult due to competition. Therefore, in the case of organizing a commercial company, the participation of regional authorities as a co-founder and guarantor of reliability is important.

Schemes of interaction between participants in creating a regional insurance company, using the Republic of Khakassia as an example, are shown in Figures 7 and 8.

First of all, the founders of a regional insurance company should be large enterprises operating in the region, as they have: sufficient financial capabilities; the opportunity to insure their risks and employees in full with one insurer and on more favorable terms; the opportunity to receive additional preferences from regional authorities in the form of preferential working conditions in the regional market for their contribution to the development of the regional economy.
Figure 8 lists the largest manufacturing enterprises operating in the Republic of Khakassia (without giving full names), which could theoretically become the founders of an insurer.

The proposed models of interaction between interested participants in insurance relations can increase the competitiveness of insurance companies in the region and improve the quality of insurance services. As a result, the main task of the regional policy will be solved, namely to increase the efficiency of the region's production potential by protecting against risks, as well as through the emergence of investment resources in the regional insurance market.

The development of the social potential of the industrial region is of particular importance, as it is about improving the health and working capacity of the population in the region. Such experience can be useful for other regions with a similar economic situation, where several large enterprises of the extractive industry form the basis, and that have no their own insurance market.

\section{CONCLUSION}

To highlight the relationship and impact of the regional insurance market on the industrial sector of the region, the paper systematizes the typology of regions, the main parameters of which were the indicators of the region's industry related to risks. Based on the results, an analysis of the Republic of Khakassia was conducted. 
The current structure of the Republic's economy is characterized by high production and manmade risks. To achieve sustainable socio-economic development of the region and, above all, the effective functioning of its manufacturing sector, effective, socially responsible insurance protection against risks is required, which is not fully implemented in the Republic of Khakassia.

Analysis of the insurance market in Khakassia showed that the region does not have its own insurance companies, and the market is represented by nonresident insurers. Mostly standard insurance services are sold, such as life insurance, accident insurance, corporate property insurance and compulsory types of insurance. The cost of voluntary insurance is overvalued, and the level of insurance coverage is limited compared to other regions of the Siberian Federal District and to average figures in Russia.

Factors in the development of the insurance market in the Republic of Khakassia are the mono-industry structure of the economy, the presence of man-made and natural risks, insufficient budget provision of the region, weak investment attractiveness and innovation activity, low income of citizens. These factors determine the limited demand for insurance services, primarily in the field of voluntary insurance. To form a diversified structure of the economy in the region and, above all, to develop its manufacturing segment, it is important to stimulate insurance that reduces industrial and population risks. This, in addition to providing insurance coverage, will promote insurance investment in the regional economy, job creation, and additional implementation of other activities in the region. Priority types of insurance should be industrial risk insurance, investment insurance, health insurance, and home insurance. The specific effect of the regional insurance market should be realized based on the development and implementation of insurance programs, the content of which should be related to the needs of the regional manufacturing sector in insurance coverage.

\section{AUTHOR CONTRIBUTIONS}

Conceptualization: Evgenija Prokopjeva, Galina Chernova.

Data curation: Galina Chernova, Svetlana Kalayda.

Formal analysis: Evgenija Prokopjeva, Nataliya Kuznetsova.

Funding acquisition: Evgenija Prokopjeva, Svetlana Kalayda.

Investigation: Evgenija Prokopjeva, Galina Chernova, Nataliya Kuznetsova, Svetlana Kalayda.Leonid Ivanov.

Methodology: Evgenija Prokopjeva, Galina Chernova, Nataliya Kuznetsova.

Project administration: Evgenija Prokopjeva, Nataliya Kuznetsova.

Resources: Evgenija Prokopjeva, Nataliya Kuznetsova.

Software: Leonid Ivanov.

Supervision: Nataliya Kuznetsova, Leonid Ivanov.

Validation: Svetlana Kalayda, Leonid Ivanov.

Visualization: Evgenija Prokopjeva.

Writing - original draft: Evgenija Prokopjeva, Galina Chernova.

Writing - review \& editing: Galina Chernova.

\section{ACKNOWLEDGMENT}

The paper was written under the grant from the Russian Foundation for Basic Research - Development of a Methodology for Green and Infrastructure Investment by Institutional Investors in the Context of Pension Reforms. 


\section{REFERENCES}

1. All-Russian public organization Green Patrol. National environmental rating of regions. (2018). Retrieved from https://greenpatrol. $\mathrm{ru} / \mathrm{ru} /$ stranica-dlya-obshchegoreytinga/ekologicheskiy-reytingsubektov-rf?tid=368

2. Alyakina, D. P., Kajgorodova, G. N., \& Pyrkova, G. H. (2018). Osobennosti upravleniya riskami regionalnoy strahovoy kompanii [Features of risk management of a regional insurance company]. Kazanskiy ekonomicheskiy vestnik - Kazan economic bulletin, 2(32), 12-18. (In Russian). Retrieved from https://elibrary.ru/item. asp? $\mathrm{id}=36874870$

3. Arkhipov, A. P., Bazanov, A. N., Belozerov, S. A., Boldyreva, N. B., Galkina, E. Yu., Gamankov, D. V., Gamankova, O. A., Gvarliani, T. E., Grebenshchikov, E. S., Domnina, O. L., Dymnich, O. V., Zelenitsa, I. M., Kalayda, S. A., Kirillova, N, V., Komarova, N. V., Kudriavtsev, A. A., Kuznetsova, N, P., Logvinova, I. L., Nosanenko, G. Yu., ... Velickiene, M. (2017). Strahovaniye i upravleniye riskami: problemy $i$ perspektivy [Insurance and risk management: problems and perspectives] (528 p.). Moscow: Prospekt. (In Russian). Retrieved from https://elibrary.ru/item. asp? $\mathrm{id}=29093240$

4. Belozyorov, S. A., Chernova, G. V., \& Kalayda, S. A. (2018). Sovremennyye faktory razvitiya rossiyskogo strakhovogo rynka [Modern factors of development of the Russian insurance market]. Strahovoe delo - Insurance business, 6, 31-35. (In Russian). Retrieved from https://elibrary.ru/item. asp?id=35104759

5. Belozyorov, S. A., Pisarenko, Zh. V., \& Kuznetsova, N. P. (Ed.). (2018). Regulirovaniye strahovoy deyatelnosti [Regulation and insurance activities] 437 p. Moscow: Yurayt Publishing House. (In Russian). Retrieved from https://urait. ru/bcode/413007

6. Blake, D. (2013). Longevity risk and capital markets: The 2011-2012 Update. Journal of Risk and Insurance, 80(3), 495-
500. Retrieved from https:// www.researchgate.net/publication/48376448_Longevity_Risk_ and_Capital_Markets_The_20112012_Update

7. Chalmers, J., \& Reuter, J. (2012). How Do Retirees Value Life Annuities? Evidence from Public Employees. Review of Financial Studies, 25(8), 2601-2634. Retrieved from https://www.nber. org/papers/w15608

8. Chernova, G. V., Pisarenko, Zh. V., \& Kuznetsova, N. P. (2017). Faktory, predposylki i parametry finansovoy konvergentsii [Factors, prerequisites and parameters of financial convergence]. Strahovoe delo - Insurance business, 3, 3-13. (In Russian). Retrieved from https://elibrary.ru/item. asp?id=28880743

9. Chernyavskaya, E.Yu., \& Izyumova, O. N. (2018). Osobennosti razvitiya strakhovogo regionalnogo rynka po strakhovaniyu zhizni v Yuzhnom federalnom okruge za period 2014-2016 godov [Features of the development of the regional life insurance market in the Southern Federal Dastrict for 2014-2016]. Biznes. Obrazovanie. Pravo - Business. Education. Law, 1(42), 130-136. (In Russian). Retrieved from https://elibrary.ru/ item.asp?id=32534926

10. Domnina, O. L., \& Ovchenkova, S. E. (2018). Analiz razvitiya strakhovogo rynka PFO [Analysis of the development of the insurance market of the VFD]. Vestnik Volzhskoy gosudarstvennoy akademii vodnogo transporta - Bulletin of the Volga State Academy of Water Transport, 54, 65-70. (In Russian). Retrieved from https://elibrary.ru/ item. asp? $\mathrm{id}=32610870$

11. Efimov, O. N., \& Kochubey, I. A. (2017). Strahovoy rynok i strahovoy biznes: problema regionalnoy differentsiatsii [Insurance market and insurance business : the problem of regional differentiation]. Strahovoe delo - Insurance business, 5, 13-19. (In Russian). Retrieved from https://www.elibrary.ru/item. asp?id=29256975

12. Federal State Statistics Service.
(2019). Regiony Rossii. Socialnoekonomicheskiye pokazateli - 2018 g. [The regions of Russia. Socioeconomic indicators - 2018]. (In Russian). Retrieved from https:// rosstat.gov.ru/bgd/regl/b19_14p/ Main.htm

13. Federal State Statistics Service. (2019a). Retrieved from https:// rosstat.gov.ru/statistic

14. Gaganis, C., Hasan, I., Papadimitri. P., \& Tasiou, M. (2019). National culture and risk-taking: Evidence from the insurance industry. Journal of Business Research, 97(4), 104-116. Retrieved from https:// socionet.ru/publication.xml?h= repec:eee:jbrese:v:97:y:2019:i:c :p:104-116

15. Institute "Development Center". (2016). Kommentarii o gosudarstve $i$ biznese [Comments on the state and business], 116, June 22 - July 10. (In Russian). Retrieved from http://dcenter.hse.ru

16. Kalayda, S. A., \& Chernova, G. V. (2016). Primenenie mirovogo opyta ucheta strakhovykh riskov $\mathrm{v}$ deyatelnosti rossiyskikh strakhovshchikov [Application of global experience in accounting for insurance risks in the activities of Russian insurers]. Zbirnyk materialiv III Mizhnarodnoi naukovo-praktychnoi konferentsii «Innovatsiini napriamky rozvytku strakhovoho ryn-ku Ukrainy", 19-20 kvitnya - Collection of Materials of the $3 \mathrm{rd}$ International Scientific and Practical Conference Innovation Directly Development of the Insurance Market of Ukraine, April 19-20, 134-137. Kyiv: KHEY. Retrieved from https://pureportal.spbu.ru/ru/publications/ применение-мирового-опытаучета-страховых-рисков-вдеятельности-р

17. Keneshova, K. D. (2018). Razvitiye regionalnogo strashovogo rynka [Development of the regional insurance market]. Sinergiya Nauk - Synergy of sciences, 21, 67-79. (In Russian). Retrieved from https:// elibrary.ru/item.asp?id=32706832

18. Kirillova, N. V. (2018). Sovershenstvovaniye regionalnoy strakhovoy politiki v 2018-2020 gg. [Im- 
proving the regional insurance policy in 2018-2020]. Ekonomika. Nalogi. Pravo - Economics. Taxes. Law, 11(1), 83-88. (In Russian). Retrieved from https://elibrary.ru/ item.asp? $\mathrm{id}=32502618$

19. KonsultantPlus. (2007). Zakon RF ot 29.11.2007 № 286-FZ “O vzaimnom strahovanii” [Law of the Russian Federation "On mutual insurance" dated November 29, 2007, No. 286-FZ]. (In Russian). Retrieved from http:// www.consultant.ru/document/ cons_doc_LAW_72848/

20. KonsultantPlus. (2014). Rasporiazheniye Pravitelstva Rossiyskoy Federatsii № 1398-r ot 29 iyulia 2014 goda "O perechne monoprofilnykh munitsipalnykh obrazovaniy Rossiyskoy Federatsii (monogorodov)" [Decree of the Government of the Russian Federation No. 1398-r dated July 29, 2014 "On the list of single-industry municipalities of the Russian Federation (mono-industry towns)"]. (In Russian). Retrieved from http:// www.consultant.ru/document/ cons_doc_LAW_166540/

21. Kuzmenkova, V. D. (2016). Ustoychivoye razvitiye regionov Rossii [Sustainable development of Russian regions]. Vestnik Voronezhskogo gosudarstvennogo universiteta inzhenernykh tekhnologiy - Bulletin of Voronezh State University of Engineering Technologies, 2, 257-261. (In Russian). Retrieved from https://elibrary.ru/item. asp?id=26774473

22. Kuznetsov, Yu. V. (2014). Gosudarstvennoye strategicheskoye upravleniye [State strategic management] (320 p.). St. Petersburg. (In Russian). Retrieved from https://publications.hse.ru/ books/77741973

23. Kuznetsova, N. P., \& Pisarenko, Zh. V. (2017). Financial convergence in the global financial market: prospects for pension funds and insurance corporations, the EU and China. Problems of Modern Economy, 1(61), 102-106. Retrieved from https://www.elibrary.ru/item. asp?id=29334111

24. Kuznetsova, N. P., Chernova, G. V., Prokopjeva, E. L., \& Boldyreva, N. B. (2019). Governance of factors for the regional insurance market development (evidence from Russia). Problems and Perspectives in Management, 17(3), 491-507. Retrieved from https://businessperspectives.org/journals/problemsand-perspectives-in-management/ issue-326/governance-of-factorsfor-the-regional-insurance-market-development-evidence-fromrussia

25. Laux, C., \& Muermann, A. (2010). Financing risk transfer under management problems: mutual versus stock insurers. Journal of Financial Intermediation, 19(3), 333-354. Retrieved from https:// papers.ssrn.com/sol3/papers. cfm?abstract_id $=908860$

26. Lee, H. S., Yong, Z. J., \& Lim, Q. M. (2018). Insurance Development and Economic Growth. Financial Statistical Journal, 1, 1-17. Retrieved from https:// www.researchgate.net/publication/332016474_Insurance_Development_and_Economic_Growth

27. Lobo-Guerro, L. (2014). The capitalization of "excess life" through life insurance. Global Society, 3, 300-316. Retrieved from https://www.researchgate.net/ profile/Luis_Lobo-Guerrero

28. Mdanat, M., Kasasbeh, H. A., \& Abushaikha, I. (2019). The Effect of Insurance Activity on per Capita Income in the Southern Mediterranean: An Empirical Analysis Using Jordan as a Case Study. Theoretical Economics Letters, 18, 912-928. Retrieved from https:// www.scirp.org/journal/paperinformation. aspx? paperid $=91860$

29. Ministry of Finance of the Republic of Khakassia. (2019). Retrieved from https://r-19.ru/authorities/ ministry-of-finance-of-the-republic-of-khakassia/docs/6577/95001. html

30. Mnykh, M. V. (2017). Competition in the insurance market of Ukraine and the peculiarities of its control. Priority research areas. Collection of scientific articles, 79-94. Retrieved from https://www.elibrary.ru/item. asp?id=30768321

31. Mohy Ul Din, S., Regupathi, A.,
\& Abu-Bakar, A. (2017). Insurance effect on economic growthamong economies in various phases of development. Review of International Business and Strategy, 27(4), 501-519. Retrieved from https://www.scilit.net/article/4452 01d7be491dfb7b392c94887f26c8

32. Njegomir, V., \& Stojić, D. (2010). Does insurance promote economic growth: The evidence from ex-Yugoslavia region. Ekonomska misao i praksa, 31-48. Retrieved from https://www.researchgate. net/publication/229024117_Does_ insurance_promote_economic growth_the_evidence_from_exYugoslavia_region

33. Orlaniuk-Malitskaya, L. A. (2017). Regionalnoye strakhovaniye: teoreticheskiy aspect [Regional insurance: theoretical aspect]. Strakhovoye delo - Insurance business, 9, 49-55. (In Russian). Retrieved from https://elibrary.ru/ item. asp? $\mathrm{id}=30054702$

34. Ouédraogo, I., Guérineau, S., \& Sawadogo, R. (2016). Life Insurance Development and Economic Growth: Evidence from Developing Countries. Études et Documents, 16, CERDI. Retrieved from https:// halshs.archives-ouvertes.fr/ halshs-01385002/

35. Outreville, J. F. (2013). The Relationship between insurance and economic development: 85 empirical papers for a review of the literature. Risk Management \& Insurance Review, 1, 71-122. Retrieved from https://papers.ssrn. com/sol3/papers.cfm?abstract_ $\mathrm{id}=2240106$

36. Pchela, A. V. (2016). Prioritety upravleniya socialno-ekonomicheskim razvitiyem regionov Rossii [Priorities for managing the socio-economic development of Russian regions]. Vestnik gosudarstvennogo i municipalnogo upravleniya - Bulletin of State and municipal administration, 5, 2, 51-54. (In Russian). Retrieved from https://www.elibrary.ru/item. asp? $\mathrm{id}=26673691$

37. Porrini, D. (2017). Regulating big data effects in the European insurance market. Insurance Markets and Companies, 
8, 1-16, 6-15. Retrieved from https://www.researchgate.net/ publication/317050367_Regulating_Big_Data_effects_in_the_European_insurance_market

38. Prokopjeva, E. L. (2018). Istochniki i mekhanizmy povysheniya regionalnoy effektivnosti strahovaniya [Sources and mechanisms for increasing the regional effectiveness of insurance] (208 p.). Novosibirsk: ANS "SibAK”. (In Russian). Retrieved from https://elibrary.ru/ item.asp?id=32501851

39. Prokopjeva, E. L. (2019). Sovremennyy strakhovoy rynok Rossii: problemy i potencial razvitiya [Modern Russian insurance market: problems and development potential]. Finansy $i$ kredit - Finance and credit, 25, 1(781), 177-195. (In Russian). Retrieved from https://www.fin-izdat.ru/ journal/fc/detail.php?ID=73967

40. Prokopjeva, E. L. (2020). Opyt razvitiya strakhovykh rynkov $\mathrm{v}$ raznykh tipakh stran i ego ispolzovaniye $\mathrm{v}$ Rossii [Experience in the development of insurance markets in different types of countries and its use in Russia]. Vklad strahovoy teorii i praktiki v povysheniye finansovoy gramotnosti naseleniya $v$ koordinatakh menyayushcheysia ekonomiki. Sbornik trudov XXI Mezhdunarodnoy nauchno-prakticheskoy konferencii, 102-108. Pskov. (In Russian). Retrieved from https://elibrary.ru/ item.asp?id=44155293

41. Rusetskaya, E. A. (2013). Strakhovoy rynok Rossii: problemy $i$ perspektivnyye napravleniya razvitiya [Russian insurance market: problems and perspective directions for development] (116 p.). Stavropol: ID TESERA. (In Russian). Retrieved from https://elibrary.ru/ item.asp?id=22462925

42. Shkolnyk, I., Bondarenko, E., \& Balatskyi, Ie. (2019). Financial risks of the stock market: opportunities and specifics of their insurance. Insurance Markets and Companies, 10(1), 26-35. https://doi. org/10.21511/ins.10(1).2019.034

43. Sigma. World insurance: the great pivot East continues. (2019). Swiss Re Institute sigma, 3, 45. Retrieved from https://www.swissre.com/ institute/research/sigma-research/ sigma-2019-03.html

44. Tarasova, Yu. A., \& Voskovskaya, E. S. (2018). Otsenka regionalnykh rynkov strakhovaniya i ikh vliyaniye na rossiyskiy strakhovoy rynok [Assessment of regional insurance markets and their impact on the Russian insurance market]. Strakhovoe delo - Insurance business, 10, 36-53. (In Russian). Retrieved from https://publications. hse.ru/articles/226751731

45. The Central Bank of the Russian Federation. (2019). Statisticheskiye pokazateli i informatsiya ob otdelnykh subyektakh strakhovogo dela [Statistical indicators and information on individual subjects of insurance business]. (In Russian). Retrieved from https://www.cbr. ru/finmarket/supervision/sv_insurance/

46. Tsvetova, G. V., \& Stemkovskaya, E. S. (2018). Strakhovoy rynok Dalnevostochnogo federalnogo okruga: sostoyaniye i tendentsii razvitiya [Insurance market of the Far Eastern Federal District: state and development trends]. Vlast i upravlenie na Vostoke Rossii Power and control in the east of Russia, 3(84), 36-41. (In Russian). Retrieved from https:/elibrary.ru/ item.asp?id=36891977

47. Tsyganov, A. A., \& Kirillova, N. V. (2018). Strakhovoy rynok Rossiyskoy Federatsii: regionalnyy aspekt [Insurance market of the Russian Federation: regional aspect]. Ekonomika regiona - Regional economy, 14(4), 1270-1281. (In Russian). Retrieved from https:// elibrary.ru/item.asp?id=36650359

48. Vorontsov, P. G. (2014). Vliyaniye strakhovykh kompaniy na razvitiye regionalnoy ekonomiki $v$ RF [Influence of insurance companies on the development of the regional economy in the Russian Federation]. Ekonomika i predprinimatelstvo - Economics and entrepreneurship, 7, 279-285. (In Russian). Retrieved from https:// elibrary.ru/item.asp?id=21802781

49. Yakymchuk, A., Mykytyn, T., \& Valyukh, A. (2017). Management of the nature conservation areas of Ukraine's Polissya region based on the international experience.

Problems and Perspectives in Management, 15(1-1), 183-190. http:// dx.doi.org/10.21511/ppm.15(11). 2017.05

50. Zainutdinov, R. R. (2015). Antikrizisnoye razvitiye monootraslevykh regionov Rossii [Anti-crisis development of monoindustry regions of Russia] (147 p.). Moscow: Mir Nauki. (In Russian). Retrieved from http://izd-mn. com/PDF/16MNNPM15.pdf

51. Zheng, Hui, \& Zhao, Xin (2017). The dynamic relationship between insurance development and economic growth. New evidence from China's coastal areas, 11(5), 102109. Retrieved from https://academicjournals.org/journal/AJBM/ articlereferences/7AA1C4D63368 